\title{
Leukotriene $D_{4}$-Induced Activation of Smooth-Muscle Cells From Human Bronchi Is Partly $\mathrm{Ca}^{2+}$-Independent
}

\author{
MARIA ROSA ACCOMAZZO, GIAN ENRICO ROVATI, TERESA VIGANÒ, ALICIA HERNANDEZ, ALBINO BONAZZI, \\ MANLIO BOLLA, FRANCESCA FUMAGALLI, SERENA VIAPPIANI, ELISABETTA GALBIATI, SAULA RAVASI, \\ CHIARA ALBERTONI, MONICA DI LUCA, ANTONIO CAPUTI, PIERO ZANNINI, GIUSEPPE CHIESA, \\ ANNA MARIA VILLA, SILVIA MARIA DOGLIA, GIANCARLO FOLCO, and SIMONETTA NICOSIA
}

Institute of Pharmacological Sciences, and Department of Biotechnology and Biosciences, University of Milan, and Department of Thoracic Surgery, Scientific Institute, St. Raffaele Hospital, Milan, Italy

Cysteine-containing leukotrienes (cysteinyl-LTs) are potent bronchoconstrictors and play a key role in asthma. We found that histamine and $\mathrm{LTD}_{4}$ markedly constrict strips of human bronchi (HB) with similar efficacy. However, in human airway smooth-muscle (HASM) cells, $\mathrm{LTD}_{4}$, at variance with histamine, elicited only a small, transient change in intracellular calcium ion concentration. HASM cells express both $\mathrm{Ca}^{2+}$-dependent and -independent isoforms of protein kinase C (PKC) (i.e., PKC- $\alpha$ and PKC- $\varepsilon$ ). Western blot analysis showed that PKC- $\alpha$ is activated by histamine and, to a lesser extent, by $\mathrm{LTD}_{4}$, whereas only $\mathrm{LTD}_{4}$ translocates PKC- $\varepsilon$. This translocation was specifically inhibited by the $\mathrm{LTD}_{4}$ antagonist pobilukast. Phorbol-dibutyrate ester (PDBu) (a PKC activator) contracted $H B$ strips to the same extent in the presence as in the absence of extra- and intracellular $\mathrm{Ca}^{2+}$. In the absence of $\mathrm{Ca}^{2+}$, $\mathrm{LTD}_{4}$ contracted HB strips to the same extent as did PDBu, suggesting the involvement of a $\mathrm{Ca}^{2+}$-independent PKC in $\mathrm{LTD}_{4}$-mediated signal transduction. PDBu-induced desensitization and the PKC inhibitor $\mathrm{H7}$ abolished the slow and sustained LTD $_{4}$-triggered contraction of $\mathrm{HB}$ strips in the absence of $\mathrm{Ca}^{2+}$, although $\mathrm{H} 7 \mathrm{did}$ not greatly affect the response in the presence of the ion. Thus, in human airways, we identified a novel $\operatorname{LTD}_{4}$ transduction mechanism linked to bronchial smooth-muscle contraction, which is

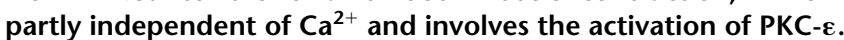

Cysteine-containing leukotrienes (cysteinyl-LTs) are pivotal inflammatory mediators formed through the 5-lipoxygenase pathway of arachidonic acid (1), and may contribute to the pathogenesis of asthma (2-4). In particular, cysteinyl-LTs are very potent constrictors of human bronchi (HB) not only in vitro (5), but also in vivo, in both normal and asthmatic individuals (6).

Among the cysteinyl-LTs, $\mathrm{LTD}_{4}$ has been studied most extensively, and is known to act through specific G-protein-coupled receptors $(7,8)$, inducing phosphoinositol hydrolysis $(9$, 10) and an increase in the cytosolic $\mathrm{Ca}^{2+}$ concentration (intracellular $\left.\left[\mathrm{Ca}^{2+}\right] ;\left[\mathrm{Ca}^{2+}\right]_{\mathrm{i}}\right)(11-13)$. The latter effect in particular occurs in tracheal smooth-muscle cells (14).

Differences exist between cell types with respect both to the role of $\mathrm{Ca}^{2+}$ and to the mechanisms of the $\mathrm{LTD}_{4}$-induced increase in $\left[\mathrm{Ca}^{2+}\right]_{\mathrm{i}}(15)$. For instance, $\mathrm{LTD}_{4}$ can induce either $\mathrm{Ca}^{2+}$ influx through the plasma membrane without any $\mathrm{Ca}^{2+}$ release from intracellular stores $(11,12)$, or $\mathrm{Ca}^{2+}$ release without influx (16), and, in many cell types can induce both $\mathrm{Ca}^{2+}$ influx and release $(9,13,14)$.

The role of $\mathrm{Ca}^{2+}$ in muscle contraction has been investigated for many years: $\mathrm{Ca}^{2+}$-dependent phosphorylation of

(Received in original form December 7, 1999 and in revised form July 31, 2000) Supported by grants 97.04487.СT04 and 98.03102.СT04 from the Consiglio Nazionale delle Ricerche, Italy.

Correspondence and requests for reprints should be addressed to Prof. Simonetta Nicosia, Institute of Pharmacological Sciences, University of Milan, Via Balzaretti 9, 20133 Milan, Italy. E-mail: Simonetta.Nicosia@unimi.it

Am J Respir Crit Care Med Vol 163. pp 266-272, 2001

Internet address: www.atsjournals.org myosin light chain is a major pathway for the regulation of smooth-muscle contractile force (17). However, the force/ $\mathrm{Ca}^{2+}$ ratio is variable (18), and the mechanism of action of agonist-induced smooth-muscle contraction (pharmacomechanical coupling) may consist of an alteration of the sensitivity of the contractile apparatus to $\mathrm{Ca}^{2+}(19)$. In some instances, agonist-triggered contraction can occur with little or no change in $\left[\mathrm{Ca}^{2+}\right]_{\mathrm{i}}(17,20)$. In airway smooth muscle (ASM), including that of the human bronchus, the $\mathrm{Ca}^{2+}$-sensitivity of the contractile apparatus is very high and displays high positive cooperativity (21); quite often, the tonic activation of ASM by a variety of agonists depends on $\mathrm{Ca}^{2+}$ influx from the extracellular space $(22,23)$. However, despite the existence of voltage-operated calcium channels (VOC) in human airways (24), $\mathrm{Ca}^{2+}$-entry blockers are relatively ineffective in inhibiting bronchoconstriction in asthma, indicating that airway narrowing in asthma is mediated mainly by other means than VOCs. Accordingly, it has recently been suggested (25) that $\mathrm{LTD}_{4}$ contracts human bronchi through a receptor-operated $\mathrm{Ca}^{2+}$ channel (ROC).

The aim of the present study was to clarify whether variations in $\left[\mathrm{Ca}^{2+}\right]_{\mathrm{i}}$ play a major role in $\mathrm{LTD}_{4}$-induced contraction of $\mathrm{HB}$, or whether other signal-transduction mechanisms are involved. For this purpose, we compared the in vitro contraction of isolated $\mathrm{HB}$ with increases in $\left[\mathrm{Ca}^{2+}\right]_{\mathrm{i}}$ and protein kinase $\mathrm{C}(\mathrm{PKC})$ activation in isolated smooth-muscle cells obtained from the same tissue.

\section{METHODS}

All experiments were performed in the presence of $10 \mathrm{mM}$ cysteine to prevent metabolism of $\mathrm{LTD}_{4}(26)$.

\section{Cell Isolation Procedure}

Smooth-muscle cells from HB were isolated as previously described (27). Briefly, macroscopically normal fragments of lung were obtained at thoracotomy. Third-order bronchi were removed, under sterile conditions, the connective tissue and the epithelium were removed, and the smooth muscle was cut into pieces weighing approximately $10 \mathrm{mg}$ each. The explants were grown at $37^{\circ} \mathrm{C}$ in a humidified atmosphere of $5 \% \mathrm{CO}_{2}$ in Medium 199, with the addition of $20 \%$ ( $\mathrm{vol} / \mathrm{vol}$ ) fetal calf serum (FCS), $100 \mathrm{U} / \mathrm{ml}$ penicillin, and $100 \mu \mathrm{g} / \mathrm{ml}$ streptomycin. Cells were grown in monolayers in minimum essential medium (MEM) supplemented with $10 \%$ FCS, $100 \mathrm{U} / \mathrm{ml}$ penicillin, and 100 $\mu \mathrm{g} / \mathrm{ml}$ streptomycin, and were used between passages 3 and 8 . The cells stained positively with an antibody to smooth-muscle $\alpha$-actin.

Measurements of $\left[\mathrm{Ca}^{2+}\right]$

Human bronchial cells were seeded onto coverslips and used when they reached $100 \%$ confluence. The cells were incubated for $45 \mathrm{~min}$ at $30^{\circ} \mathrm{C}$ in the dark, with $5 \mu \mathrm{M}$ Fluo3 acetoxymethyl ester (Fluo3/AM) (28) in MEM plus $0.03 \%$ Pluronic F-127, $2.5 \mathrm{mM}$ probenecid, and $10 \mathrm{mM}$ 4-(2-hydroxyethyl)-1-piperazine- $N^{\prime}$-2-ethanesulfonic acid (HEPES). After loading, cells were washed twice with saline solution ( $\mathrm{NaCl} 145 \mathrm{mM}, \mathrm{KCl} 5 \mathrm{mM}, \mathrm{MgCl}_{2} 1 \mathrm{mM}, \mathrm{CaCl}_{2} 1.8 \mathrm{mM}$, HEPES $10 \mathrm{mM}$, 
glucose $10 \mathrm{mM}$; pH 7.4) plus $2.5 \mathrm{mM}$ probenecid, and were kept at room temperature for 15 min to complete hydrolysis of the Fluo3/AM. The coverslips were then transferred to a spectrofluorometer (Perkin Elmer LS5; Perkin Elmer Italia, Monza, Italy) cuvette, and the fluorescence of the cell preparations was monitored at $30^{\circ} \mathrm{C}(506-\mathrm{nm}$ excitation, 530-nm emission). In order to evaluate $\left[\mathrm{Ca}^{2+}\right]_{\mathrm{i}}$ from fluorescence readings, $\mathrm{F}_{\max }$ (maximal fluorescence of the system) was obtained by adding $2.7 \mu \mathrm{M}$ ionomycin and $100 \mu \mathrm{M}$ digitonin and $F_{\min }$ was obtained by measuring the autofluorescence of cells that were not exposed to Fluo3/AM (29). $\left[\mathrm{Ca}^{2+}\right]_{\mathrm{i}}$ was determined according to the method of Tsien and colleagues (30), with $K_{\mathrm{d}}=646 \mathrm{nM}$, which was calculated by assuming a linear dependence on temperature (29). Increases in $\left[\mathrm{Ca}^{2+}\right]_{\mathrm{i}}$ were expressed as the ratio of the stimulated over the basal level $(\mathrm{s} / \mathrm{b})$.

\section{Preparation of Isolated HB}

Macroscopically normal HB (2- to 3-mm diameter) were obtained from patients undergoing thoracic surgery for pulmonary carcinoma, and were prepared as previously described (31). Briefly, the bronchi were dissected free of parenchyma and blood vessels, and were cut helically into strips 2 to $3 \mathrm{~mm}$ wide and about $10 \mathrm{~mm}$ long. The strips were suspended in organ baths containing Tyrode's solution (composition in mM: $\mathrm{NaCl}, 140 ; \mathrm{KCl}, 3 ; \mathrm{CaCl}_{2}, 1 ; \mathrm{MgCl}_{2}, 0.05 ; \mathrm{NaH}_{2} \mathrm{PO}_{4}, 0.5$; glucose, $8.4 ; \mathrm{NaHCO}_{3}, 12 ; \mathrm{pH} 7.4$ ) at $37^{\circ} \mathrm{C}$, which was bubbled with $95 \% \mathrm{O}_{2}-$ $5 \% \mathrm{CO}_{2}$. Contractions were measured with a Basile 7004 isometric force transducer (Ugo Basile, Comerio, Italy) and recorded on a Basile Gemini 7070 polygraph. Bronchial strips were set at an initial tension of $1 \mathrm{~g}$ and repeatedly washed over a 60 -min equilibration period. Contractions are expressed as the percent of the contraction induced by $300 \mu \mathrm{M}$ acetylcholine $(\mathrm{ACh})$. When necessary, the Tyrode's solution was replaced after $\mathrm{ACh}$ administration, with a solution lacking $\mathrm{Ca}^{2+}$ and containing $1 \mathrm{mM}$ ethylene glycol-bis-( $\beta$-aminoethyl ether)- $N, N, N^{\prime}, N^{\prime}$-tetraacetic acid (EGTA) and $1 \mu \mathrm{M}$ thapsigargin to eliminate intra- and extracellular calcium. At the end of experiments with calcium- depleted strips, contractility was verified by addition of $30 \mathrm{mM} \mathrm{BaCl}_{2}$.

\section{Cell Contraction}

Cells were grown in monolayers in Petri dishes as described earlier, and were used at submaximal (95\%) confluence. Cell contraction was recorded by measuring the increase in intercellular spaces by means of a TV camera connected to an inverted light microscope (Axiovert; $\times 20$ lens; Zeiss, Jena, Germany) coupled to an image analyzer (a Macintosh computer [Apple Computer, Inc., Cupertino, CA] running NIH Image v.1.62, developed by Dr. Wayne Rasband, of the National Institutes of Health, Bethesda, MD) through a Data Translation Inc. (Marlboro, MA) QuickCapture frame grabber card. Images were collected for $15 \mathrm{~min}$ (one frame every $30 \mathrm{~s}$ ). After $5 \mathrm{~min}$ of recording of the control state, either histamine or $\mathrm{LTD}_{4}$ was added. When necessary, intra- and extracellular $\mathrm{Ca}^{2+}$ was removed as described earlier.

Image intensity is reported on a scale of 255 Gray Units with 0 for white and 255 for black. The background intensity level (empty Petri dishes) was determined to be in the range of 0 to 50 of Gray Units, and all Gray-level readings of 50 or lower were converted to a red color to represent intercellular spaces and to compute the percent increase in intensity over the basal state.

\section{Laser Scanning Confocal Fluorescence Microscopy}

Cells were grown in monolayers on chamber slides and loaded with Fluo3/AM as described earlier. The chamber slide was placed on a thermostatically controlled copper plate $\left(\right.$ at $30^{\circ} \mathrm{C}$ ) on the stage of a confocal microscope (MRC-600; Bio-Rad, Microsciences Division, Hemel Hempstead, UK) coupled to an upright epifluorescence microscope (Optiphot-2; Nikon, Tokyo, Japan). The indicated concentrations of histamine or $\mathrm{LTD}_{4}$ were added to the cells with a microsyringe. Intracellular Fluo3 fluorescence in single living cells was measured by confocal microscopy. Argon ion laser excitation was used at $488 \mathrm{~nm}$, and the power of the laser was kept at low values $(<0.1 \mathrm{~mW})$ to preserve cell viability and to avoid possible saturation of the fluorescence signal. Fluorescence emission was detected in the photon-counting mode with a photomultiplier (S20 Thorn-EMI-9890; Bio-Rad Microsciences Division, Hemel, Hempstead, UK) through a long pass filter at wavelengths above $515 \mathrm{~nm}$. The indicator fluorescence was followed in a field of view of about $400 \times 300 \mu^{2}$, in which about 10 cells were inspected at the same time through a $\times 20$ air objective. The scan speed of the laser excitation was set to $0.25 \mathrm{~s}$ for a frame of $384 \times 256$ pixels. Under these conditions, a single scan of the field of view enabled us to obtain an excellent fluorescence image at a confocal aperture of about $2 \mathrm{~mm}$ and a numerical aperture of 0.4 . A temporal resolution of $2 \mathrm{~s}$ was used. The time course of the indicator fluorescence was followed by using the time series option of the MRC-600 COMOS software.

Image fluorescence intensities were recorded on a scale of 256 Gray Units (from 0 for black to 255 for peak white). False colors were assigned to four ranges of Gray-Unit values, corresponding to four ranges of $\mathrm{Ca}^{2+}$ concentrations, as shown in Figure 7. The time dependences of fluorescence intensities were studied in selected areas inside single cells (about 40 to $80 \mu^{2}$ wide), in which the mean $\mathrm{Ca}^{2+}$ concentrations were evaluated.

\section{Evaluation of PKC Translocation}

Smooth-muscle cells were incubated for $18 \mathrm{~h}$ in culture medium without FCS, and were then treated with the agents being investigated at $37^{\circ} \mathrm{C}$ for $5 \mathrm{~min}$, unless otherwise indicated. The incubation was stopped at $4^{\circ} \mathrm{C}$ and the cells were washed twice in cold phosphate-buffered saline (PBS). Cells were then lysed at $4^{\circ} \mathrm{C}$ for $30 \mathrm{~min}$ in $20 \mathrm{mM}$ Tris- $\mathrm{HCl}$, pH 7.4, containing $2 \mathrm{mM}$ EGTA, $20 \mathrm{mM}$ ethylenediamine tetraacetic acid (EDTA), $0.1 \mathrm{mM}$ phenylmethylsulfonyl fluoride (PMSF), $1 \mathrm{mM}$ dithiothreitol (DTT), and a set of protease inhibitors (Complete; Boehringer Mannheim, Mannheim, Germany). The lysed suspension was centrifuged at $100,000 \times g$ for $60 \mathrm{~min}$, with the supernatant comprising the cytosolic fraction. The pellet was resuspended in lysis buffer plus $0.1 \%$ Triton $\mathrm{X}-110$ at $4^{\circ} \mathrm{C}$ for $45 \mathrm{~min}$, and centrifugation was then repeated, with the resulting supernatants representing the membrane fraction. The proteins in the cytosolic and membrane fractions were separated by sodium dodecylsulfate-polyacrylamide gel electrophoresis (running gel: acrylamide 11\%), and were electroblotted onto nitrocellulose paper. PKC isozymes were evaluated by Western blot analysis, utilizing polyclonal antibodies raised against PKC- $\alpha$ (at a dilution of $1: 1,500$ ) and PKC- $\varepsilon$ (at a dilution of $1: 1,000$ ) for $1 \mathrm{~h}$ at $25^{\circ} \mathrm{C}$. After washing with Tris-buffered saline (TBS) containing $0.1 \%$ Tween-20, the sheets were incubated $\left(1 \mathrm{~h}, 25^{\circ} \mathrm{C}\right)$ with peroxidase-conjugated antirabbit IgG $(1: 3,000)$ and washed as described previously. Antigenantibody complexes were detected by enhanced chemiluminescence. Results were analyzed with a computer-assisted image analysis program (NIH Image v.1.62), and were expressed as percents of PKC translocation versus basal conditions.

\section{Statistical Analysis}

Statistical analysis of the concentration-response curves for $\left[\mathrm{Ca}^{2+}\right]_{\mathrm{i}}$ versus histamine or $\mathrm{LTD}_{4}$ was done with the ALLFIT computer program (32), which calculates lower and upper plateaus, slope, and $\mathrm{EC}_{50}$ values, and allows the comparison of two or more curves. Selection of the best fitting model and evaluation of the statistical significance of parameter differences was based on the $F$ test for the extra-sum-ofsquares principle (33). All curves shown in the illustrations were computer generated.

Statistical comparison of multiple groups was done through oneway analysis of variance followed by Bonferroni's post hoc test. A statistical level of significance of $p<0.05$ was accepted. Data are expressed as mean \pm SE. Each experiment was performed at least three times and, when possible, in triplicate.

\section{Materials}

TBS, PBS, Hanks' balanced salt solution (HBSS), Medium 199, Eagle's MEM, trypsin-EDTA, EGTA, penicillin $(10,000 \mathrm{U} / \mathrm{ml})$, streptomycin $(10 \mathrm{mg} / \mathrm{ml})$, L-glutamine (200 mM), H7, dimethylsulfoxide, ACh, histamine, probenecid, atropine, pyrilamine, L-cysteine, thapsigargin, phorbol-dibutyrate ester (PDBu), anti-smooth-muscle $\alpha$-actin antibody, peroxidase-conjugated antirabbit IgG, PMSF, and DTT were from Sigma Chemical Co., St. Louis, MO. Antibodies to the PKC- $\alpha$ and PKC- $\varepsilon$ isoforms, were from Boheringer Mannheim. LTD $_{4}$ was from Cayman Chemical Co., Ann Arbor, MI. All salts for Tyrode's solution were from Merck, Darmstadt, Germany. FCS was from PBI International, Milan, Italy. Disposable culture flasks, Petri dishes, and filters were from Corning Glassworks, Corning, NY. Fluo3/AM and 

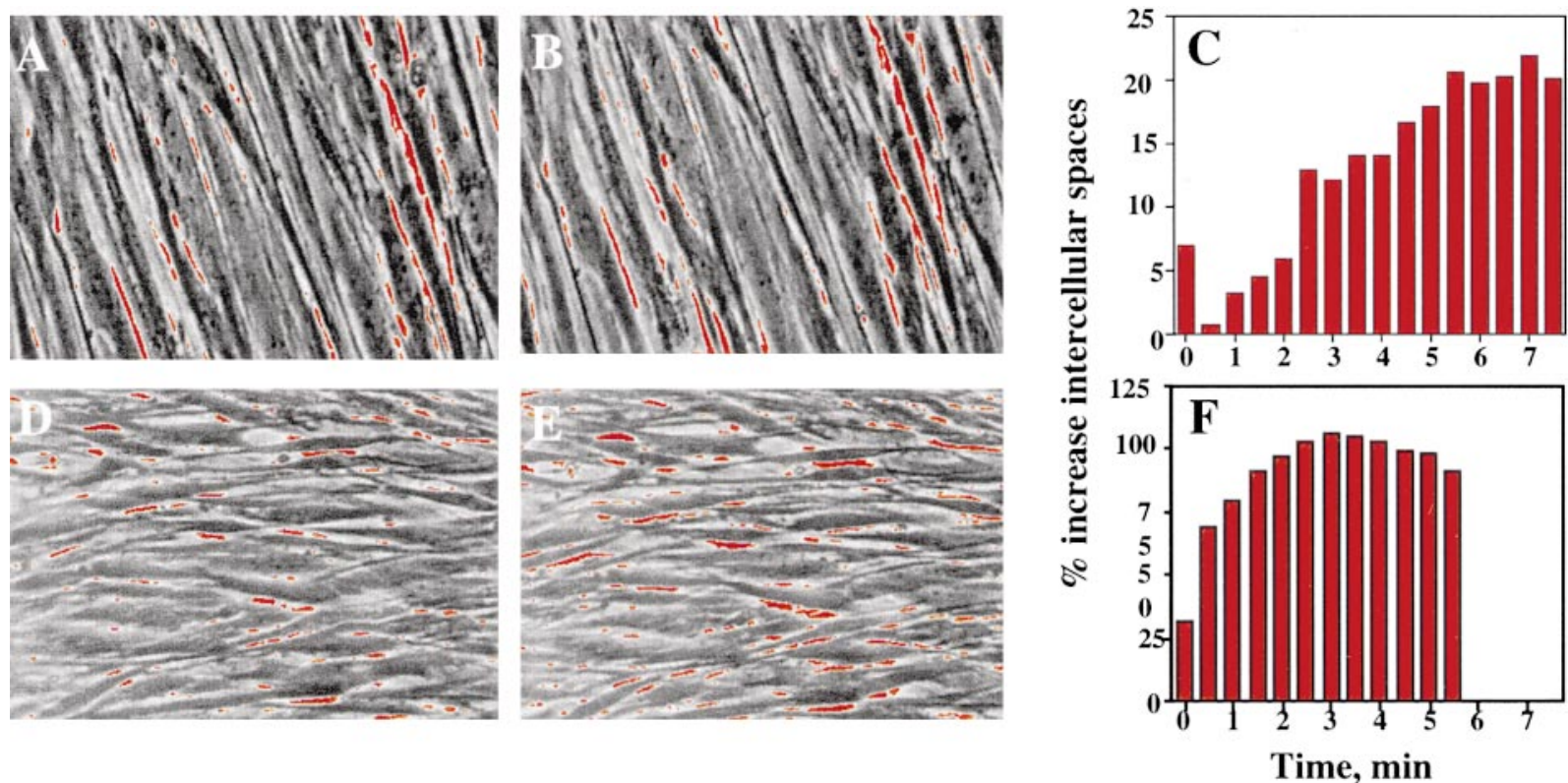

Figure 1. Light microscopic images of HASM cells made with a false-color map. Cell images are given in a scale of $256 \mathrm{Gray}$-Unit levels (from 0 for white to 255 for black); of red color (0 to 50 Gray-Unit levels) represents intercellular spaces. Cells were used at submaximal (95\%) confluence. ( $A$ ) Control cells. (B) Same field as in $A$ after stimulation with $0.3 \mu \mathrm{M} \mathrm{LTD}{ }_{4}(8 \mathrm{~min})$. (C) Time-course of the percent increase in intercellular spaces induced by $\mathrm{LTD}_{4}$ (data from $A$ and $B$ ); frames were recorded at 30 -s intervals. $(D)$ Control cells. (E) Same field as in $D$ after stimulation with $100 \mu M$ histamine (5 min). $(F)$ Time-course of the percent increase in intercellular spaces induced by histamine (data from $D$ and $E$ ); frames were recorded at 30-s intervals. The experiments were performed in the presence of $1 \mathrm{mM}$ extracellular $\mathrm{Ca}^{2+}$.

pluronic F-127 were purchased from Molecular Probes, Eugene, OR. MK 571 was a generous gift from Dr. A. W. Ford-Hutchinson of Merck Frosst, Point Dorval, PQ, Canada, and SKF 104353 was kindly provided by Dr. A. von Sprecher of the Research Department, Pharmaceutical Division, Novartis Ltd., Basel, Switzerland.

\section{RESULTS}

\section{Contraction of Human Airway Smooth-Muscle Cells and of Isolated Strips of HB}

Contraction of human airway smooth-muscle (HASM) cells in monolayers was recorded by measuring the increase in intercellular spaces by means of an image analyzer coupled to a light microscope. $\mathrm{LTD}_{4}$ was able to contract HASM cells to the same extent in the presence of $\mathrm{Ca}^{2+}(30 \pm 8 \%$ [mean \pm $\mathrm{SE}$ ] increase in intercellular spaces, $\mathrm{n}=6$; Figures $1 \mathrm{~A}$ and $1 \mathrm{~B}$ ) as in its absence (which was effected by pretreatment with $1 \mathrm{mM}$ EGTA and $300 \mathrm{nM}$ thapsigargin, to eliminate extraand intracellular $\mathrm{Ca}^{2+}$, respectively) $(28 \pm 3 \%, \mathrm{n}=3$, data not shown). The time-course of the increase in intercellular space in the same field is shown in Figure 1C. On the contrary, the effect of histamine, albeit generally greater than that of $\mathrm{LTD}_{4}$ $(66 \pm 9 \%, n=6$; Figures $1 \mathrm{D}$ and $1 \mathrm{E})$, was greatly decreased by the absence of $\mathrm{Ca}^{2+}(26 \pm 9 \%, \mathrm{n}=3$, data not shown $)$. Figure $1 \mathrm{~F}$ shows the time course of the effect of histamine. The concentration of thapsigargin used and the preincubation time were sufficient to deplete the sensitive cytoplasmic stores of $\mathrm{Ca}^{2+}$ as assessed by $\left[\mathrm{Ca}^{2+}\right]_{i}$ measurement (data not shown).

Both $\mathrm{LTD}_{4}$ (Figure 2A) and histamine (Figure 2B) caused marked concentration-dependent bronchoconstriction with comparable efficacy in isolated strips of $\mathrm{HB}$. The calculated $\mathrm{EC}_{50}$ values for $\mathrm{LTD}_{4}$ and histamine are summarized in Table 1.

\section{$\left[\mathrm{Ca}^{2+}\right]_{i}$ Increase in a Population of HASM Cells and in Single HASM Cells}

In a population of HASM cells, $\mathrm{LTD}_{4}$ (Figure 2C) was able to elicit only a very modest, if any, transient increase in $\left[\mathrm{Ca}^{2+}\right]_{\mathrm{i}}$ (maximum $\left[\mathrm{Ca}^{2+}\right]_{\mathrm{i}}$ increase: $\mathrm{s} / \mathrm{b}=1.8 \pm 0.35$ ). On the contrary, the response to histamine (Figure 2D) was concentration-dependent $\left(\mathrm{EC}_{50}=30 \mu \mathrm{M}\right)$, with a marked increase in $\left[\mathrm{Ca}^{2+}\right]_{\mathrm{i}}$ (maximum increase: $\mathrm{s} / \mathrm{b}=8.9 \pm 0.89$ ). Representative traces showing the $\left[\mathrm{Ca}^{2+}\right]_{\mathrm{i}}$ increases evoked by $1 \mu \mathrm{M} \mathrm{LTD}_{4}$
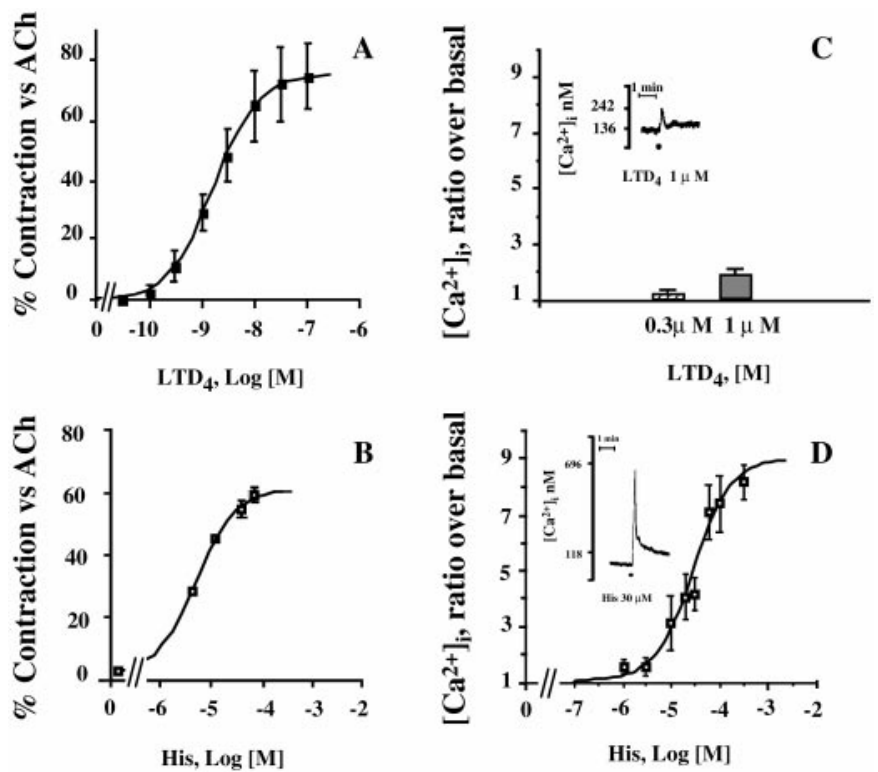

Figure 2. Concentration-response curves of agonist-induced contraction $(A$ and $B)$ of isolated human bronchi, and $\left[\mathrm{Ca}^{2+}\right]_{\mathrm{i}}$ increase $(C$ and $D)$ in HASM cells. ( $A$ and $C)$ LTD $_{4}$. ( $B$ and $D$ ) Histamine. Insets in $C$ and $D$ are representative tracings of the individual effect of agonist concentrations in inducing $\left[\mathrm{Ca}^{2+}\right]_{\mathrm{i}}$ increases. Curves in $A$ and $B$ were constructed with strips from seven different lung specimens. Curves in $C$ and $D$ were obtained from four to seven experiments on cells obtained from three to five different lung specimens, respectively. 
TABLE 1

POTENCY OF HISTAMINE AND LTD $_{4}$ IN INDUCING CONTRACTION OF HUMAN BRONCHIAL STRIPS AND $\mathrm{Ca}^{2+}$ INCREASE IN CELLS

\begin{tabular}{lccccc}
\hline & \multicolumn{2}{c}{ Contraction } & & \multicolumn{2}{c}{$\left[\mathrm{Ca}^{2+}\right]_{\mathrm{i}}$ Increase } \\
\cline { 2 - 3 } \cline { 6 - 7 } Agonist & & $\mathrm{CV}$ & & $\mathrm{CV}$ \\
& $\mathrm{EC}_{50}$ & $(\%)$ & & $\mathrm{EC}_{50}$ & $(\%)$ \\
\hline Histamine & $3.7 \mu \mathrm{M}$ & 11 & & $30 \mu \mathrm{M}$ & 29 \\
$\mathrm{LTD}_{4}$ & $1.6 \mathrm{nM}$ & 5 & & $\mathrm{ND}$ & $\mathrm{ND}$ \\
\hline
\end{tabular}

Definition of abbreviations: $\left[\mathrm{Ca}^{2+}\right]_{\mathrm{i}}=$ intracellular calcium-ion concentration; $\mathrm{CV}=$ coefficient of variation; $\mathrm{EC}_{50}=$ effective concentration causing $50 \%$ of maximal effect; $\mathrm{LTD}_{4}=$ leukotriene $\mathrm{D}_{4} ; \mathrm{ND}=$ not determined.

and $30 \mu \mathrm{M}$ histamine, respectively, are shown as insets in Figures $2 \mathrm{C}$ and $2 \mathrm{D}$. The response was completely abolished by $5 \mathrm{~min}$ of preincubation with specific antagonists (i.e., $1 \mu \mathrm{M}$ MK 571 and $30 \mu \mathrm{M}$ mepyramine) (data not shown).

$\left[\mathrm{Ca}^{2+}\right]_{\mathrm{i}}$ transients in single HASM cells loaded with Fluo3 were studied with confocal fluorescence microscopy. Figure 3 shows the false-color images of cells under basal conditions (Figure 3A) and at $40 \mathrm{~s}$ (Figure 3B), corresponding to the peak $\left[\mathrm{Ca}^{2+}\right]_{i}$ value, after stimulation with $100 \mu \mathrm{M}$ histamine. Figures $3 \mathrm{C}$ and $3 \mathrm{D}$ (48 s) show the results obtained with $1 \mu \mathrm{M}$ $\mathrm{LTD}_{4}$. Figures $4 \mathrm{~A}$ and $4 \mathrm{~B}$ show the mean $\left[\mathrm{Ca}^{2+}\right]_{\mathrm{i}}$ increase in response to histamine and $\mathrm{LTD}_{4}$, respectively, as a function of time, measured in the cells indicated in Figure 3, as well as the effect elicited by the vehicle alone (0.1\% EtOH; Figure $3 \mathrm{C})$. It is clear that the effect of $\mathrm{LTD}_{4}$ was not much greater than that of the appropriate control, whereas histamine elicited a much greater increase in $\left[\mathrm{Ca}^{2+}\right]_{\mathrm{i}}$. Furthermore, the specific antagonist SKF $104353(10 \mu \mathrm{M})$ decreased the $\mathrm{LTD}_{4}$ response by only a slight degree (data not shown).

\section{Role of PKC in Contraction}

Figures 5A through 5D show the contraction tracings for isolated strips of $\mathrm{HB}$ prepared from adjacent segments chal-
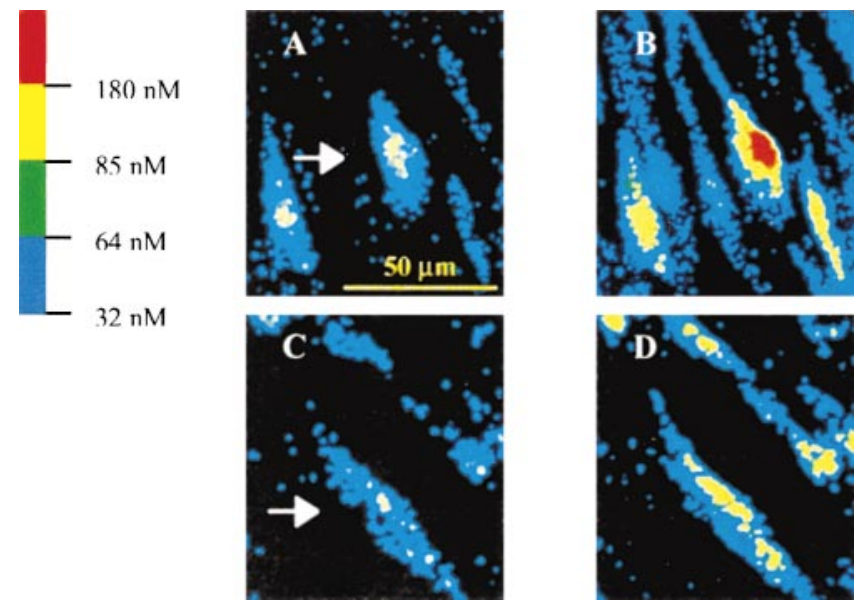

Figure 3. False-color confocal fluorescence microscopic images of HASM cells loaded with the fluorescent $\mathrm{Ca}^{2+}$ probe Fluo3. (A) Resting cells. (B) Appearance at $40 \mathrm{~s}$ after the addition of $100 \mu \mathrm{M}$ histamine. (C) Resting cells. (D) Appearance at $48 \mathrm{~s}$ after the addition of $1 \mu \mathrm{M} \mathrm{LTD}{ }_{4}$. Fluorescence intensities were recorded on a scale of 256 Gray-Unit levels and divided into four ranges, corresponding to four ranges of $\left[\mathrm{Ca}^{2+}\right]_{\mathrm{i}}$ concentrations, to which pseudocolors were assigned. Images shown are representative of seven or eight other experiments (for $\mathrm{LTD}_{4}$ and histamine, respectively) on cells obtained from three to five different lung specimens. lenged with $\mathrm{LTD}_{4}(0.3 \mu \mathrm{M})$. Compound H7 (50 $\left.\mu \mathrm{M}\right)$, an inhibitor of PKC, did not affect $\mathrm{LTD}_{4}$-induced contraction in the presence of $\mathrm{Ca}^{2+}$ (Figure 5B), whereas in the absence of $\mathrm{Ca}^{2+}$ it abolished the residual contraction usually present (compare Figures 5C and 5D). Moreover, in the absence of $\mathrm{Ca}^{2+}$, repeated in vitro administration of the $\mathrm{PKC}$ activator $\mathrm{PDBu}$ $(1 \mu \mathrm{M})$ completely inhibited $\mathrm{LTD}_{4}$-induced contraction of bronchial strips (Figure 5E).

When the strips were stimulated with $0.3 \mu \mathrm{M} \mathrm{LTD}$, the removal of extra- and intracellular $\mathrm{Ca}^{2+}$ markedly decreased, but did not abolish, the contraction (Figures 6 and 5C). On the contrary, the effect of $\mathrm{PDBu}$, which induced a slowly developing contraction (Figure 5E), was not affected by removal of $\mathrm{Ca}^{2+}$ (Figure 6). In the case of histamine, no contraction was detectable in the absence of $\mathrm{Ca}^{2+}$ (data not shown).

\section{Translocation of Different Isoforms of PKC}

Figure 7 shows a representative Western blot analysis performed with polyclonal antibodies to PKC- $\alpha$, a calcium-dependent isoform of $\mathrm{PKC}$, and to $\mathrm{PKC}-\varepsilon$, a calcium-independent isoform of the enzyme, on membrane proteins of HASM cells incubated with either $\mathrm{LTD}_{4}$ or histamine. $\mathrm{LTD}_{4}$ at $0.3 \mu \mathrm{M}$ induced marked activation of the calcium-independent PKC- $\varepsilon$ $(170 \pm 15 \%$; Figure $7 \mathrm{~B})$ and, to a lesser extent, of the calciumdependent PKC- $\alpha$ isoform (116 $\pm 17 \%$; Figure 7A), whereas incubation with $100 \mu \mathrm{M}$ histamine produced marked translocation only of the calcium-dependent PKC- $\alpha$ isoform (514 \pm $181 \%$; Figure 7A). The effect of LTD $_{4}$ on PKC- $\varepsilon$ was time-dependent, being maximal after $5 \mathrm{~min}$ of incubation and progressively decreasing at 15 and $30 \mathrm{~min}$ (Figure 7C), thus suggesting

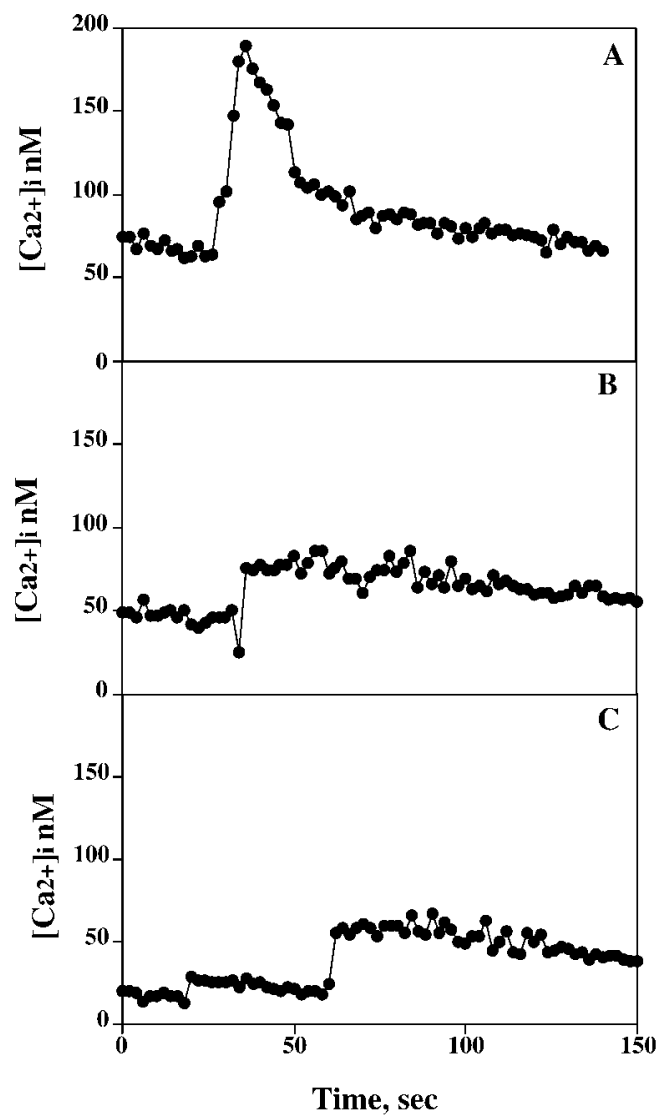

Figure 4. Mean $\left[\mathrm{Ca}^{2+}\right]_{\mathrm{i}}$ as a function of time with $(A) 100 \mu \mathrm{M}$ histamine and (B) $1 \mu \mathrm{M} \mathrm{LTD}$. Measurements were made in the cells indicated in Figure 3. (C) Effect of vehicle $(0.1 \% \mathrm{EtOH})$ for $\mathrm{LTD}_{4}$ alone. 

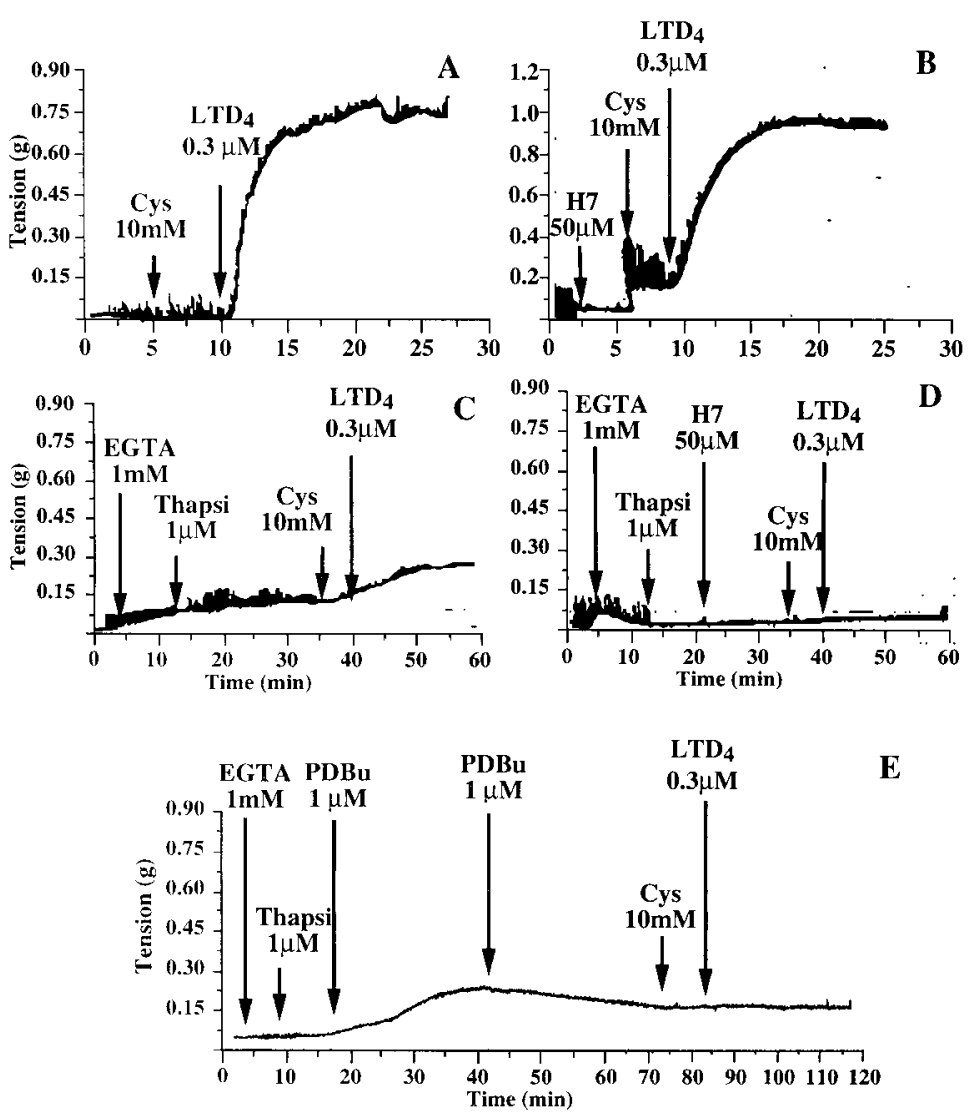

Figure 5. Representative tracings of contraction of isolated strips of $\mathrm{HB}$ in response to $0.3 \mu \mathrm{MLTD}$. $(A$ and $B)$ Tracings in the presence of $\mathrm{Ca}^{2+}$ in the absence $(A)$ and in the presence $(B)$ of $50 \mu \mathrm{M}$ H7. ( $C$ through $E$ ) Tracings in the absence of $\mathrm{Ca}^{2+}$ in the absence $(C)$ and in the presence $(D)$ of $50 \mu \mathrm{M} \mathrm{H7}$. (E) Tracing made after repeated administration of $1 \mu \mathrm{M}$ PDBu. The tracings are representative of two or three other tracings. that prolonged incubation induces downregulation of this isoform of the kinase. Figure 7D shows a Western blot analysis of membrane proteins of cells incubated with increasing concentrations of $\mathrm{LTD}_{4} \cdot \mathrm{LTD}_{4}(5 \mathrm{nM}$ and $0.3 \mu \mathrm{M})$ increased the translocation of PKC- $\varepsilon$ by $143 \% \pm 21$ and $105 \pm 16$, respectively. In addition, $10 \mu \mathrm{M}$ of SKF 104353 was able to counteract the effect of the highest concentration of $\mathrm{LTD}_{4}$.

As expected, removal of $\mathrm{Ca}^{2+}$ abolished $\mathrm{LTD}_{4}$-induced translocation of PKC- $\alpha$, but it did not affect the translocation of PKC- $\varepsilon$ (Figure 8).

\section{DISCUSSION}

$\mathrm{LTD}_{4}$ is a potent constrictor of smooth muscle, including bronchial smooth muscle. In most tissues and cells, this effect has been shown to be receptor-mediated and coupled to an increase in $\left[\mathrm{Ca}^{2+}\right]_{i}(7,15)$. Smooth-muscle contraction has been directly correlated with either an increase in $\left[\mathrm{Ca}^{2+}\right]_{\mathrm{i}}$ (in the guinea pig ileal longitudinal muscle [12]) or with an increased hydrolysis of phosphatydyl inositol in lung [8]). On the con-

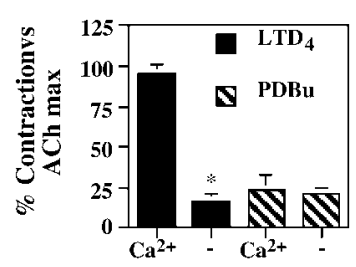

Figure 6. Contraction of isolated strips of $\mathrm{HB}$ in the presence or absence of intracellular and extracellular $\mathrm{Ca}^{2+}$. Bars represent the mean \pm SE. Closed bars: $\mathrm{LTD}_{4}$ at $0.3 \mu \mathrm{M}$; hatched bars: PDBu at $1 \mu \mathrm{M}$. ${ }^{*} \mathrm{p}<$ 0.05 versus addition of $\mathrm{Ca}^{2+}$ (one-way analysis of variance, $\mathrm{n}=4$ ). trary, we found that a discrepancy exists between contraction and increased $\left[\mathrm{Ca}^{2+}\right]_{i}$ in bronchial tissue. In fact, $\mathrm{LTD}_{4}$ was able to contract strips of human bronchus in vitro to an extent comparable with that elicited by histamine, albeit with much higher potency, but was much less efficient in inducing an increase in $\left[\mathrm{Ca}^{2+}\right]_{\mathrm{i}}$ in isolated smooth-muscle cells obtained from the same organ.

One possible explanation for this discrepancy would be the loss during cell isolation and culture of the $\mathrm{LTD}_{4}$ receptor that was responsible for contraction. However, this hypothesis can be ruled out, because the cultured cells actually responded to $\mathrm{LTD}_{4}$ with measurable contractions that were inhibited by MK-571, a specific $\mathrm{LTD}_{4}$ receptor antagonist. Another possible explanation would be a heterogeneity in the $\left[\mathrm{Ca}^{2+}\right]_{\mathrm{i}}$ response in the cell population examined, with the cells either not being synchronized in their $\mathrm{Ca}^{2+}$ response or with few cells expressing the receptor and therefore responding with an increase in $\left[\mathrm{Ca}^{2+}\right]_{\mathrm{i}}$. Laser scanning confocal fluorescence microscopy allowed us to measure $\left[\mathrm{Ca}^{2+}\right]_{\mathrm{i}}$ variations in single HASM cells, and demonstrated that the percentage of cells responding to $\mathrm{LTD}_{4}$ with increases in $\left[\mathrm{Ca}^{2+}\right]_{\mathrm{i}}$ was not lower than that responding to histamine. Furthermore, the time-course of $\mathrm{Ca}^{2+}$ variation in response to $\mathrm{LTD}_{4}$ did not vary significantly from cell to cell. The data obtained at the single-cell level therefore confirmed those obtained in the overall cell population, showing a marked difference in the peak $\left[\mathrm{Ca}^{2+}\right]_{\mathrm{i}}$ level with histamine as opposed to $\mathrm{LTD}_{4}$, and excluding a heterogeneous cell response as the cause of the discrepant effect of $\mathrm{LTD}_{4}$.

Thus, our data demonstrate a dissociation between $\mathrm{LTD}_{4^{-}}$ induced contraction and increased $\left[\mathrm{Ca}^{2+}\right]_{i}$ elevation and suggest that $\mathrm{Ca}^{2+}$-independent mechanisms contribute to $\mathrm{LTD}_{4^{-}}$ triggered bronchoconstriction in human airways. Indeed, mea- 
MEMBRANE FRACTION PKC $\alpha$.

$\mathbf{A}$

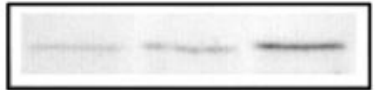

MEMBRANE FRACTION PKC $\varepsilon$

B

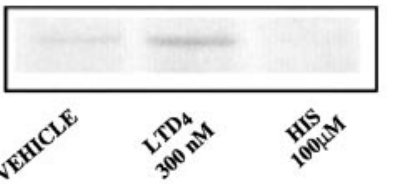

MEMBRANE FRACTION PKC $\varepsilon$
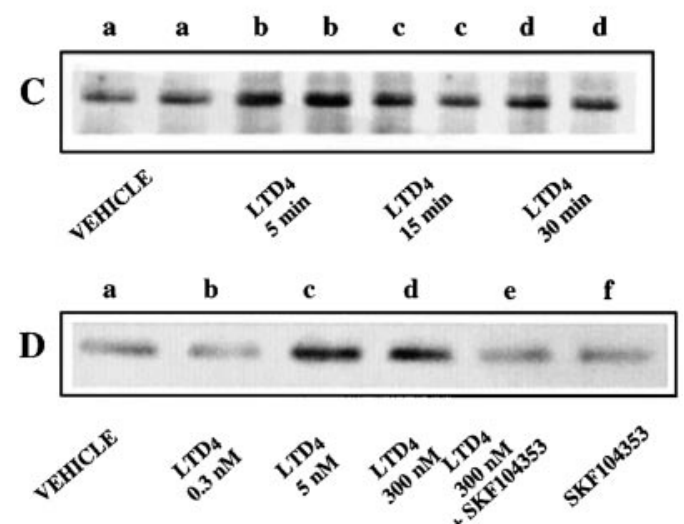

Figure 7. Western blot analysis done with antibodies to PKC- $\alpha$ and PKC $-\varepsilon$ on membrane proteins from HASM cells incubated with vehicle, $\mathrm{LTD}_{4}$, or histamine. $(A)$ Effect of $\mathrm{LTD}_{4}(0.3 \mu \mathrm{M})$ or histamine $(100 \mu \mathrm{M})$ on translocation of PKC- $\alpha$ to the membrane. (B) Effect of $\operatorname{LTD}_{4}(0.3 \mu \mathrm{M})$ or histamine $(100 \mu \mathrm{M})$ on translocation of PKC- $\varepsilon$. (C) Time-course of

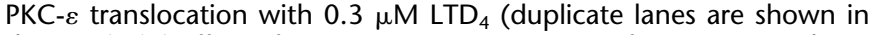
this case). (D) Effect of increasing concentrations of $\mathrm{LTD}_{4}$ on translocation of PKC $-\varepsilon$. The last two lanes represent the effect of $10 \mu \mathrm{M}$ SKF 104353 on translocation of PKC- $\varepsilon$ in cells stimulated with $0.3 \mu \mathrm{M} \mathrm{LTD}$ or in resting cells, respectively. Vehicle was MEM supplemented with $100 \mathrm{U} / \mathrm{ml}$ penicillin, $100 \mu \mathrm{g} / \mathrm{ml}$ streptomycin, and $10 \mathrm{mM}$ cysteine. In $(D)$ vehicle contained also $0.7 \%$ DMSO.

surement of single-cell contraction by light microscopy shows that the removal of extra- and intracellular $\mathrm{Ca}^{2+}$ elicits only a minor reduction in cell contraction induced by $\mathrm{LTD}_{4}$ from that observed in the presence of $\mathrm{Ca}^{2+}$. On the contrary, histamine-induced contraction was substantially reduced (by more than $50 \%$ ) in the absence of $\mathrm{Ca}^{2+}$. This indicates that in isolated HASM cells, the histamine response depends largely on the presence of $\mathrm{Ca}^{2+}$, whereas the $\mathrm{LTD}_{4}$ response is largely $\mathrm{Ca}^{2+}$-independent.

In seeking a $\mathrm{Ca}^{2+}$-independent mechanism for $\mathrm{LTD}_{4}$-mediated bronchoconstriction, we postulated an involvement of PKC in $\mathrm{LTD}_{4}$-mediated signal transduction. Indeed, it is known that: (1) $\mathrm{LTD}_{4}$ can activate PKC $(7,34)$; (2) $\mathrm{LTD}_{4}$-triggered contraction in $\mathrm{HB}$ is rather slow, but is sustained in time; (3) $\mathrm{PKC}$ is involved in the sustained phase of smooth-muscle contraction in general (35) and in HASM cells in particular (36, 37); and (4) HASM cells express different isoforms of PKC (38), some of which $(\delta, \theta, \varepsilon$, and $\eta)$ are $\mathrm{Ca}^{2+}$ independent.

Thus, using polyclonal antibodies against specific PKC isoforms (i.e., PKC- $\alpha$ ) as representatives of the classical $\mathrm{Ca}^{2+}$ dependent isoforms of $\mathrm{PKC}$, and against $\mathrm{PKC}-\varepsilon$ as a representative of the $\mathrm{Ca}^{2+}$-independent isoforms, we investigated their activation. $\mathrm{LTD}_{4}$ was able to translocate PKC- $\varepsilon$ and, to a lesser extent, $\mathrm{PKC}-\alpha$, whereas histamine was able to translocate only PKC- $\alpha$. The activation of PKC- $\varepsilon$ by $\mathrm{LTD}_{4}$ was con-

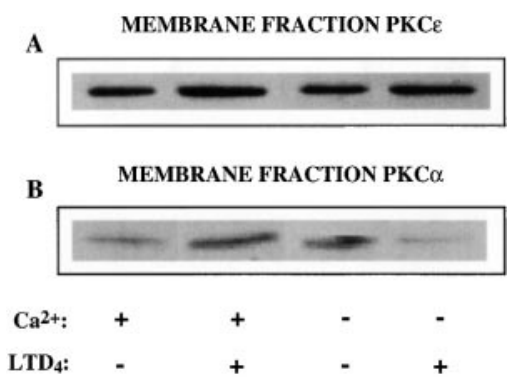

Figure 8. Western blot analysis done with antibodies to PKC- $\alpha$ and PKC- $\varepsilon$ on membrane proteins from HASM cells incubated with $0.3 \mu \mathrm{M}$ $\mathrm{LTD}_{4}$ in the presence or absence of extracellular Ca ${ }^{2+}$. Effect of $\mathrm{LTD}_{4}$ on translocation of PKC- $\varepsilon(A)$ and PKC- $\alpha(B)$ in the presence (first two lanes) and absence (last two lanes) of $\mathrm{Ca}^{2+}$. Control samples contained MEM supplemented with $100 \mathrm{U} / \mathrm{ml}$ penicillin, $100 \mu \mathrm{g} / \mathrm{ml}$ streptomycin, and $10 \mathrm{mM}$ cysteine.

centration- and time-dependent. The decrease in PKC- $\varepsilon$ translocation at 15 and $30 \mathrm{~min}$, with respect to $5 \mathrm{~min}$, might suggest a desensitization of the enzyme. This result is in agreement with the tachyphylaxis displayed by $\mathrm{LTD}_{4}$ as a contractile agent (39). Furthermore, inhibition of $\mathrm{LTD}_{4}$-induced translocation of PKC by SKF 104353, a cysteinyl-LT 1 antagonist, showed that the activation was receptor-mediated.

To further link PKC activation and contraction of $\mathrm{HB}$, we evaluated the effect of PDBu, a PKC activator, on strips of $\mathrm{HB}$. PDBu was able to contract $\mathrm{HB}$ to the same extent in the presence as in the absence of extra- and intracellular $\mathrm{Ca}^{2+}$. These data are apparently at variance with the previously reported $(37,40)$ finding that removal of extracellular $\mathrm{Ca}^{2+}$ abolished PDBu-induced HB contraction; however, the investigators who reported this generated cumulative concentration-response curves for PDBu, in which desensitization of PKC yields a response lower than the one obtained by singledose administration, as also confirmed by Yang and Black (40). In our hands, the slowly developing and sustained contraction of $\mathrm{HB}$ seemed to be $\mathrm{Ca}^{2+}$-independent.

Interestingly, in the absence of $\mathrm{Ca}^{2+}, \mathrm{LTD}_{4}$ was able to contract $\mathrm{HB}$ to the same extent as was $\mathrm{PDBu}$, thus suggesting the involvement of a $\mathrm{Ca}^{2+}$-independent $\mathrm{PKC}$ isoform in $\mathrm{LTD}_{4}$-mediated signal transduction. This is confirmed by the complete inhibition, in the absence of $\mathrm{Ca}^{2+}$, of the $\mathrm{LTD}_{4}$ response caused by PDBu-induced desensitization of PKC. In addition, the PKC inhibitor $\mathrm{H} 7$ abolished the slow and sustained contraction triggered by $\mathrm{LTD}_{4}$ in the absence of $\mathrm{Ca}^{2+}$. The relatively minor effect of $\mathrm{H} 7$ on the response to $\mathrm{LTD}_{4}$ in the presence of $\mathrm{Ca}^{2+}$ suggests the involvement of mechanisms other than PKC activation (possibly activation of myosin light-chain kinase [41]) in the rapid phase of $\mathrm{LTD}_{4}$ contraction. Thus, the $\mathrm{LTD}_{4}$-induced response in $\mathrm{HB}$ consists of both a $\mathrm{Ca}^{2+}$-dependent phase (responsible for the onset of contraction) and a slower, $\mathrm{Ca}^{2+}$-independent phase (responsible for the maintenance of contractile tone). On the contrary, histamine-induced contraction of $\mathrm{HB}$ is completely $\mathrm{Ca}^{2+}$-dependent.

In conclusion, our data, taken collectively, indicate that in human airways, $\mathrm{LTD}_{4}$-induced contraction is at least in part independent of increases in $\mathrm{Ca}^{2+}$, and this might represent an extreme form of the increase in $\mathrm{Ca}^{2+}$ sensitivity induced by agonists (19). Such $\mathrm{Ca}^{2+}$-independent contraction involves the activation of one of the novel isoforms of PKC (i.e., PKC- $\varepsilon$ ), and indeed, PKC activation has been proposed as a mechanism of increased force development at constant $\left[\mathrm{Ca}^{2+}\right]_{\mathrm{i}}(42)$. The nature of the transduction pathway involved will be the subject of future research. However, one can speculate that 
the $\mathrm{LTD}_{4}$ receptor is coupled to phospholipase D activation, yielding diacylglycerol formation (and thus PKC activation) without concomitant formation of $\mathrm{Ca}^{2+}$. Additionally, our data support the existence of a link between $\mathrm{LTD}_{4}$-induced activation of a $\mathrm{Ca}^{2+}$-independent PKC and bronchial smooth-muscle contraction. This pathway, which is specific for $\mathrm{LTD}_{4}$ (being abolished by two different receptor antagonists and not shared by histamine), represents a novel transduction mechanism for cysteinyl-LTs.

Acknowledgment: The authors gratefully acknowledge Dr. A. von Sprecher of the Research Department, Pharmaceutical Division, Novartis Ltd., Basel, Switzerland, for providing SKF 104353, Dr. A. W. Ford-Hutchinson of Merck Frosst, Canada, for MK 571, Dr. E. Gianazza for the $\alpha$-actin measurement, and Prof. Bolo Castano for helpful discussion on smooth-muscle cell characterization.

\section{References}

1. Murphy RC, Hammarström S, Samuelsson B. Leukotriene C: slow-reacting substance from murine mastocytoma cells. Proc Natl Acad Sci USA 1979;76:4275-4279.

2. Drazen JM, Austen KF. Leukotrienes and airway responses. Am Rev Respir Dis 1987;136:985-998.

3. Chanarin N, Johnston SL. Leukotrienes as a target in asthma therapy. Drugs 1994;47:12-24.

4. Barnes PJ, Chung KF, Page CP. Inflammatory mediators of asthma: an update. Pharmacol Rev 1998;50:517-572.

5. Dahlén S-E, Hedqvist P, Hammarström S, Samuelsson B. Leukotrienes are potent constrictors of human bronchi. Nature 1980;288:484-486.

6. Barnes NC, Piper PJ, Costello JF. Comparative effects of inhaled leukotriene $\mathrm{C}_{4}$, leukotriene $\mathrm{D}_{4}$, and histamine in normal human subjects. Thorax 1984;39:500-504.

7. Crooke ST, Mattern M, Sarau H, Winkler J, Balcarek J, Wong A, Bennett CF. The signal transduction system of the leukotriene $\mathrm{D}_{4}$ receptor. Trends Pharmacol Sci 1989;10:103-107.

8. Mong S, Hoffman K, Wu H-L, Crooke ST. Leukotriene-induced hydrolysis of inositol lipids in guinea pig lung: mechanism of signal transduction for leukotriene- $\mathrm{D}_{4}$ receptors. Mol Pharmacol 1987;31:35-41.

9. Mong S, Wu H-L, Wong A, Sarau HM, Crooke ST. Leukotriene $\mathrm{D}_{4}$ receptor-mediated phosphoinositol hydrolysis and calcium mobilization in rat basophilic leukemic cells. J Pharmacol Exp Ther 1988;247:803-813.

10. Badr KF, Mong S, Hoover RL, Schwartzberg M, Ebert J, Jacobson HR, Harris RC. Leukotriene $\mathrm{D}_{4}$ binding and signal transduction in rat glomerular mesangial cells. Am J Physiol 1989;257:F280-F287.

11. Baud L, Goetzl EJ, Koo CH. Stimulation by leukotriene $\mathrm{D}_{4}$ of increases in the cytosolic concentration of calcium in dimethylsulfoxide-differentiated HL-60 cells. J Clin Invest 1987;80:983-991.

12. Oliva D, Accomazzo MR, Giovanazzi S, Nicosia S. Correlation between leukotriene $\mathrm{D}_{4}$-induced contraction and cytosolic calcium elevation: a quantitative and simultaneous evaluation in smooth muscle. $J$ Pharmacol Exp Ther 1994;268:159-166.

13. Sjölander A, Grönroos E, Hammarström S, Andersson T. Leukotriene $\mathrm{D}_{4}$ and $\mathrm{E}_{4}$ induce transmembrane signaling in human epithelial cells: single cell analysis reveals diverse pathways at the G-Protein level for the influx and the intracellular mobilization of $\mathrm{Ca}^{2+}$. J Biol Chem 1990; 265:20976-20981.

14. Mong S, Miller J, Wu H-L, Crooke ST. Leukotriene $\mathrm{D}_{4}$ receptor-mediated hydrolysis of phosphoinositide and mobilization of calcium in sheep tracheal smooth muscle cells. J Pharmacol Exp Ther 1988;244: 508-515.

15. Nicosia S, Capra V, Accomazzo MR, Galbiati E, Ragnini D, Saponara R, Novarini S, Rovati GE. Receptors and second messengers for CysLeukotrienes. In: Folco GC, Samuelsson B, Maclouf J, Velo GP, editors. Eicosanoids: from biotechnology to therapeutic applications. New York: Plenum Press; 1996. p. 127-136

16. Bouchelouche PN, Ahnfelt-Ronne I, Thomsen MK. $\mathrm{LTD}_{4}$ increases cytosolic free calcium and inositol phosphates in human neutrophils: inhibition by the novel $\mathrm{LTD}_{4}$ receptor antagonist, SR2640, and possible relation to modulation of chemotaxis. Agents Actions 1990;29:299-307.

17. Kamm KE, Stull JT. Regulation of smooth muscle contractile elements by second messengers. Annu Rev Physiol 1989;51:299-313.

18. Kamm KE, Grange RW. Calcium sensitivity of contraction. In: Barany M, editor. Biochemistry of smooth muscle contraction. San Diego: Academic Press; 1996. p. 355-365

19. Himpens B, Kitazawa T, Somlyo AP. Agonist-dependent modulation of
$\mathrm{Ca}^{+}$sensitivity in rabbit pulmonary artery smooth muscle. Pflugers Arch 1990;417:21-28.

20. Collins EM, Walsh MP, Morgan KG. Contraction of single vascular smooth muscle cells by phenylephrine at constant $\left[\mathrm{Ca}^{+}\right]$i. Am J Physiol 1992;262:H754-H762.

21. Savineau J-P, Marthan R. Activation properties of chemically skinned fibres from human isolated bronchial smooth muscle. J Physiol (Lond) 1994; 474:433-438.

22. Farley JM, Miles PR. The sources of calcium for acetylcholine-induced contractions of dog tracheal smooth muscle. J Pharmacol Exp Ther 1978;207:340-346.

23. Murray RK, Kotlikoff MI. Receptor-activated calcium influx in human airway smooth muscle cells. J Physiol (Lond) 1991;435:123-144.

24. Marthan R, Martin C, Amedee T, Mironneau J. Calcium channel currents in isolated smooth muscle cells from human bronchus. J Appl Physiol 1989;66:1706-1714.

25. Gorenne I, Labat C, Gascard JP, Norel X, Nashashibi N, Brink C. Leukotriene D4 contractions in human airways are blocked by SK\&F 96365, an inhibitor of receptor-mediated calcium entry. J Pharmacol Exp Ther 1998;284:549-552.

26. Snyder DW, Aharony D, Dobson P, Tsai BS, Krell RD. Pharmacological and biochemical evidence for metabolism of peptide leukotrienes by guinea-pig airway smooth muscle in vitro. J Pharmacol Exp Ther 1984;231:224-229.

27. Viganò T, Habib A, Hernandez A, Bonazzi A, Boraschi D, Lebret M, Cassina E, Maclouf J, Sala A, Folco G. Cyclooxygenase-2 and synthesis of $\mathrm{PGE}_{2}$ in human bronchial smooth-muscle cells. Am J Respir Crit Care Med 1997;155:864-868.

28. Kao JP, Harootunian AT, Tsien RY. Photochemically generated cytosolic calcium pulses and their detection by fluo-3. J Biol Chem 1989;264: 8179-8184.

29. Merritt JE, McCarthy SA, Davies MP, Moores KE. Use of fluo-3 to measure cytosolic $\mathrm{Ca}_{2}^{+}$in platelets and neutrophils: loading cells with the dye, calibration of traces, measurements in the presence of plasma, and buffering of cytosolic Ca2 ${ }^{+}$. Biochem J 1990;269:513-519.

30. Tsien RY, Pozzan T, Rink TJ. Calcium homeostasis in intact lymphocytes: cytoplasmic free calcium monitored with a new, intracellularly trapped fluorescent indicator. J Cell Biol 1982;94:325-338.

31. Bolla M, Caruso P, Giossi M, Folco GC, Civelli M, Sala A. Comparative analysis of isolated human bronchi contraction and biosynthesis of cysteinyl leukotrienes using a direct 5-lipoxygenase inhibitor. Biochem Pharmacol 1997;54:437-442.

32. De Lean A, Munson PJ, Rodbard D. Simultaneous analysis of families of sigmoidal curves: application to bioassay, radioligand assay, and physiological dose-response curves. Am J Physiol 1978;235:E97-E102.

33. Draper NR, Smith H. Applied regression analysis. New York: Wiley; 1966.

34. Howard S, Chan-Yeung M, Martin L, Phaneuf S, Salari H. Polyphosphoinositide hydrolysis and protein kinase $\mathrm{C}$ activation in guinea pig tracheal smooth muscle cells in culture by leukotriene $\mathrm{D}_{4}$ involve a pertussis toxin sensitive G-protein. Eur J Pharmacol 1992;227:123-129.

35. Lee MW, Severson DL. Signal transduction in vascular smooth muscle: diacylglycerol second messengers and PKC action. Am J Physiol 1994; 267:C659-C678.

36. Yang KX, Black JL. The involvement of protein kinase C in the contraction of human airway smooth muscle. Eur J Pharmacol 1995;275:283-289.

37. Rossetti M, Savineau JP, Crevel H, Marthan R. Role of protein kinase C in nonsensitized and passively sensitized human isolated bronchial smooth muscle. Am J Physiol 1995;268:L966-L971.

38. Carlin S, Yang KX, Donnelly R, Black JL. Protein kinase C isoforms in human airway smooth muscle cells: activation of PKC-zeta during proliferation. Am J Physiol 1999;276:L506-L512.

39. Hedqvist P, Dahlén S-E, Bjork J. Pulmonary and vascular actions of leukotrienes. In: Samuelsson B, Paoletti P, editors. Advances in prostaglandin, thromboxane, and leukotriene research. New York: Raven Press; 1982. p. 187-200.

40. Yang KX, Black JL. Protein kinase $\mathrm{C}$ induced changes in human airway smooth muscle tone: the effects $\mathrm{Ca}^{+}$and $\mathrm{Na}^{+}$transport. Eur J Pharmacol 1996;315:65-71.

41. Somlyo AP, Somlyo AV. Signal transduction and regulation in smooth muscle. Nature 1994:372:231-236.

42. Masuo M, Reardon S, Ikebe M, Kitazawa T. A novel mechanism for the $\mathrm{Ca} 2^{+}$-sensitizing effect of protein kinase $\mathrm{C}$ on vascular smooth muscle: inhibition of myosin light chain phosphatase. J Gen Physiol 1994; 104:265-286. 